\title{
INDEPENDENT PROGNOSTIC ROLE OF p16 EXPRESSION IN LUNG CANCER
}

Angela M. Groeger ${ }^{\mathrm{a}, \mathrm{b}}$

Mario Caputic

Vincenzo Esposito ${ }^{\mathrm{a}, \mathrm{c}}$

Antonio De Luca ${ }^{\text {a,d }}$

Luigi Bagella ${ }^{\mathrm{a}}$

Carmen Pacilio ${ }^{\mathrm{a}}$

Walter Klepetko ${ }^{\mathrm{b}}$

Giovan G. Giordano ${ }^{\mathrm{e}}$

Feliciano Baldi ${ }^{\mathrm{e}}$

Hans E. Kaiser ${ }^{\mathrm{f}}$

Ernst Wolner ${ }^{\mathrm{b}}$

Antonio Giordano ${ }^{\mathrm{a}}$
Objectives: The cyclin-dependent kinase p16 (also known as Ink4A, Mts1, Cdkn2, and Cdkn4i) has been proposed as a tumor suppressor gene mapped on chromosome segment 9p21. This study evaluated p16 protein expression in 135 lung cancer specimens and investigated potential genetic alterations occurring in this gene. Results: We found altered p16 immunohistochemical expression to be a frequent event in lung cancer and to be independent of either the histologic type or any other clinicalpathologic feature. Western blot analyses performed on about one third of the specimens correlated highly with these results. In addition, we found p16 immunohistochemical expression to be a favorable prognostic factor in lung cancer in that its reduction or loss correlated with a worse outcome for the patients. Polymerase chain reaction amplification and direct sequencing of p16 exons 1 and 2 revealed no mutations, indicating that p16-altered expression in lung cancer is not necessarily linked to mutational events of these genes. Conclusions: We conclude that p16-altered expression is both an independent and frequent event in lung cancer and may have an important role in tumorigenesis and in malignant progression of a significant proportion of these cancers. However, the actual incidence and relevance of p16 mutations in this neoplasm continues to be debated, and its analysis seems inconclusive. Our results suggest a prognostic role for the immunodetection of this protein on formalin-fixed and paraffin-embedded specimens. They further suggest its routine use in the evaluation of the frequently unpredictable behavior of lung cancer. (J Thorac Cardiovasc Surg 1999; 118:529-35)
$\mathrm{T}$ he pathogenesis of lung cancer is characterized by its multiplicity of origins. Different agents (biological, chemical, and physical), by acting as initiating or promoting factors, have been associated with increasing lung cancer risk. A common molecular basis, however, underlies all of the different pathogenetic theories. The external environment manipulates cellular proliferation and differentiation by stimulating or inhibiting certain signal transduction pathways. Each component of the

From the Department of Pathology, Anatomy and Cell Biology, Jefferson Medical College, Sbarro Institute for Cancer Research and Molecular Medicine, Philadelphia. Pa ${ }^{\mathrm{a}}$; Department of Cardio-Thoracic Surgery, University of Vienna, Vienna, Austria ${ }^{\mathrm{b}}$; Department of Respiratory Diseases, II University of Naples, Naples, Italyc; Laboratory for Cell Metabolism and Pharmacokinetics, Center for Experimental Research, Istituto Regina Elena, Rome, Italy ${ }^{\mathrm{d}}$; Department of Anatomic Pathology, II University of Naples, Naples, Italye; Department of Pathology, University of Maryland, Baltimore, Md; and Department of Experimental Pathology, University of Vienna, Vienna, Austria. ${ }^{\mathrm{f}}$

This work was supported by grants from Sbarro Institute for Cancer Research and Molecular Medicine and grants from National cell cycle machinery, being the final executors in cell division, potentially could be able to elicit or to contribute to a neoplastic phenotype. These phenomena are even more relevant in lung cancer, a neoplasm that affects the respiratory system, which is interacting continuously with the external environment.

The recent discovery of a new family of cell cycle regulators called cyclin-dependent kinase inhibitors (CKIs) has opened up new avenues for study of differ-

Institute of Health to A.G. A.D.L. is the recipient of a grant FIRC. V.E. is supported by a fellowship from the II Universitá di Napoli (Dottorato di Ricerca in Broncopneumologia).

Received for publication July 6, 1998; revisions requested Oct 22, 1998; revisions received April 19, 1999; accepted for publication April 22, 1999.

Address for reprints: Antonio Giordano, MD, $\mathrm{PhD}$, Department of Pathology, Anatomy and Cell Biology, Jefferson Medical College, Sbarro Institute for Cancer Research and Molecular Medicine, 1020 Locust St, Room 226, Philadelphia, PA 19107.

Copyright $@ 1999$ by Mosby, Inc.

0022-5223/99 $\$ 8.00+0 \quad \mathbf{1 2 / 1 / 9 9 6 0 1}$ 

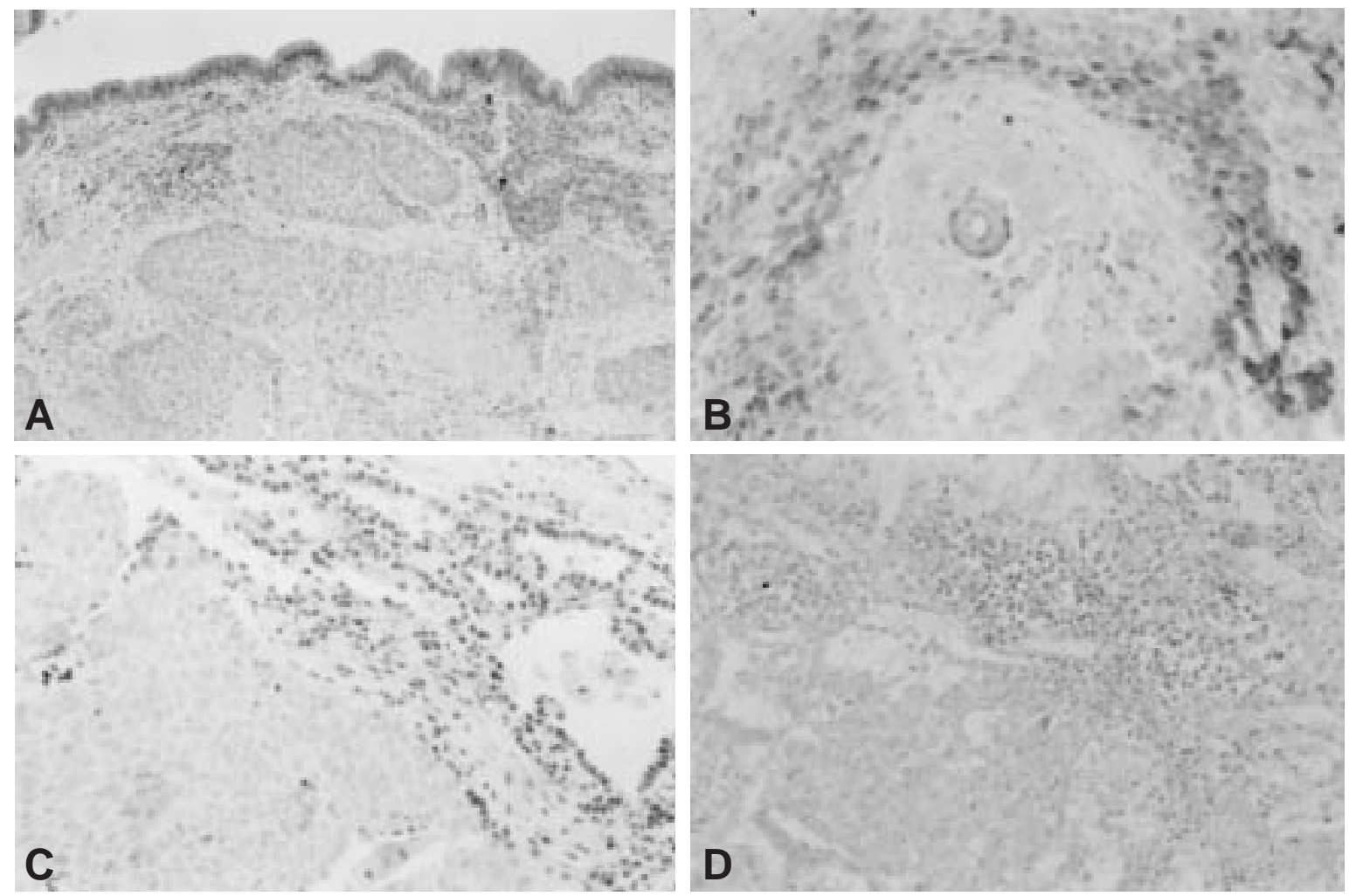

Fig 1. Representative p16 immunostainings of lung cancer specimens with the presence of staining of non-neoplastic elements (positive internal control). A, Lung cancer with high p16 expression level $(\times 200)$. B, Lung cancer with medium p16 expression level $(\times 200)$. C, Lung cancer with low p16 expression level $(\times 200)$. D, Lung cancer negative for p16 expression with a positive internal control (lymphocytes) $(\times 200)$.

ent cell cycle functions. CKIs have the ability to stop cell cycle progression by interacting directly with several cell cycle regulators and also are considered to be potential tumor suppressor genes. At present, 2 different groups of CKIs can be separated on the basis of sequence homology criteria. The first group includes p21 (WAF1, Cip1, Cap20, Sdi1, mda6), the first CKI to be discovered, p27 (Ick, Kip1 and Pic2), and p57 (also called Kip2). The second group includes p16 (Ink4A, Mts1, Cdkn2, and Cdkn4i), p15 (Ink4B, Mts2), p18 (Ink4C and Ink6A), and p19/p20 (also called Ink4D and Ink6B).

The $\mathrm{p} 16$ gene encodes a $16-\mathrm{kd}$ protein first identified in transformed cell lines. ${ }^{1}$ The detection of significant levels of p16 in late G1 and S phase only confirms its role in the inhibition of the cell cycle machine. ${ }^{2}$ In addition, p16 is believed to block the activation of cyclindependent kinases 4 and 6 by competing for $\mathrm{D}$ cyclin binding. ${ }^{1}$ Because p16 is considered to be a specific regulator of D-type cyclin-dependent kinases and because the retinoblastoma gene is the best character- ized substrate of the G1 cyclin-dependent kinases, a feedback between these 2 cell cycle regulators has been hypothesized. ${ }^{3,4}$ This theory is supported by the finding that increased levels of p16 are always detected in cells $\mathrm{Rb}-/-$, blocking the interactions between cyclindependent kinases 4 and 6 and the D cyclins. ${ }^{4}$ However, the transcription factor that should regulate this mechanism is yet to be identified.

Abnormalities in the above-described $\mathrm{p} 16 / \mathrm{Rb}$ pathway have been reported in different tumors. ${ }^{5-9}$ It is widely known that lung cancers of morphologic similarities may behave differently in any assigned stage group, which may affect markedly the clinical management of each patient. We ${ }^{10,11}$ have reported the involvement of p27 and p21 in lung cancer pathogenesis and progression. Drawing on our previous findings, we decided to assess the p16 status in a group of 135 patients who had surgical resection for lung cancer in an attempt to identify a prognostic marker for this frequent and aggressive neoplasm whose behavior often seems to be unpredictable. 


\section{Material and methods}

Tumor specimens. A total of 135 formalin-fixed and paraffin-embedded lung cancer specimens were included in the study. All specimens were obtained from patients who underwent surgical resection (lobectomy or pneumonectomy) and complete mediastinal lymphadenectomy in the Department of Cardio-Thoracic Surgery at the University Hospital of Vienna (Austria) or in the Department of Thoracic Surgery of V. Monaldi Hospital, Naples (Italy). One surgeon (A.M.G. or W.K.) from our research group was always the principal surgeon of the surgical team.

Neoplastic freshly frozen tissues also were available from 54 patients who had not undergone any adjuvant therapy. Sex was unevenly distributed, with women accounting for $21.5 \%$ of the population, and the mean patient age was 62 years.

Follow-up data were collected from the Central Institute of Statistics of Austria, from hospital charts, and from periodic interviews with patients and their families. The histologic diagnoses and classifications of the tumors were based on the World Health Organization criteria. ${ }^{12}$ The postoperative pathologic TNM stage was determined according to the guidelines of the American Joint Committee on Cancer. ${ }^{13}$

Polymerase chain reaction (PCR) and direct sequencing. Genomic DNA of normal tumor tissues was extracted from 54 micro-dissected frozen specimens, and exons 1 and 2 of the p16 gene were amplified as previously described. ${ }^{14}$ PCR products then were purified (QIAquick PCR purification kit, Germany) and sequenced by Dyedeoxy terminator reaction chemistry for sequence analysis on the Applied Biosystem model 377 DNA sequencing system (Foster City, Calif).

Western blot analysis. One gram of each frozen lung cancer tissue sample was sectioned and quickly homogenized at $4^{\circ} \mathrm{C}$ in $250 \mathrm{mmol} / \mathrm{L} \mathrm{NaCl}, 50 \mathrm{mmol} / \mathrm{L}$ tromethamine (Tris, $\mathrm{pH} 7.4), 5 \mathrm{mmol} / \mathrm{L}$ EDTA, $0.1 \%$ Triton $\mathrm{X}-100,1 \mathrm{mmol} / \mathrm{L}$ phenylmethylsulfonyl fluoride, $50 \mathrm{mmol} / \mathrm{L} \mathrm{NaF}, 0.5 \mathrm{mmol} / \mathrm{L}$ $\mathrm{Na}_{3} \mathrm{VO}_{4}, 10 \mathrm{mg} / \mathrm{mL}$ leupeptin, and $50 \mathrm{mg} / \mathrm{mL}$ aprotinin. The homogenates were cleared by centrifugation for 15 minutes at $13,000 \mathrm{~g}$ at $4^{\circ} \mathrm{C}$, and the total protein in the extracts was determined. Next, $50 \mathrm{mg}$ of protein was denatured by boiling in $2 \mathrm{X}$ Laemmli sample buffer and separated by electrophoresis in a $15 \%$ sodium dodecyl sulfate-polyacrylamide gel, followed by electrophoretic transfer of the proteins to a PVDF membrane (Millipore, Bedford, Mass) in CAPS buffer (10 $\mathrm{mmol} / \mathrm{L}$ CAPS, $20 \%$ methanol, $\mathrm{pH} 11)$. The membrane then was blocked with $5 \%$ milk in TBS-T buffer $(2 \mathrm{mmol} / \mathrm{L}$ tromethamine [Tris], $13.7 \mathrm{mmol} / \mathrm{L} \mathrm{NaCl}, 0.1 \%$ Tween-20, $\mathrm{pH}$ 7.6) and washed in TBS-T. Monoclonal mouse anti-p16 (F12) dilution $1 \mu \mathrm{g} / \mathrm{mL}$ (Santa Cruz Biotechnology, Inc, Santa Cruz, Calif) was incubated with the membrane in $3 \%$ milk and then washed in TBS-T. Secondary antibody, anti-mouse coupled to horseradish peroxidase, was incubated with the membrane and then washed in TBS-T. The presence of secondary antibody bound to the membrane was detected by using the ECL system (DuPont NEN Company, Boston, Mass).

Immunohistochemistry. Sections from each specimen were cut at 3 to $5 \mu \mathrm{m}$, mounted on glass, and dried overnight
Table I. Frequency of distribution of clinical-pathologic factors

\begin{tabular}{|c|c|c|}
\hline Factor & $N$ & $\%$ \\
\hline \multicolumn{3}{|l|}{ Sex } \\
\hline Male & 106 & 79 \\
\hline Female & 29 & 21 \\
\hline \multicolumn{3}{|l|}{ Age (y) } \\
\hline$\leq 60$ & 50 & 37 \\
\hline$>60$ & 85 & 63 \\
\hline \multicolumn{3}{|l|}{ Histologic type } \\
\hline Adenocarcinoma & 58 & 43 \\
\hline Squamous & 54 & 40 \\
\hline Small cell carcinoma & 22 & 16 \\
\hline Unknown & 1 & 1 \\
\hline \multicolumn{3}{|l|}{ Tumor size } \\
\hline $\mathrm{T} 1$ & 34 & 25 \\
\hline $\mathrm{T} 2$ & 74 & 55 \\
\hline $\mathrm{T} 3$ & 9 & 7 \\
\hline $\mathrm{T} 4$ & 7 & 5 \\
\hline Tx & 11 & 8 \\
\hline \multicolumn{3}{|l|}{ Nodal involvement } \\
\hline No & 48 & 36 \\
\hline N1 & 42 & 31 \\
\hline $\mathrm{N} 2$ & 24 & 18 \\
\hline N3 & 2 & 1 \\
\hline $\mathrm{Nx}$ & 19 & 14 \\
\hline \multicolumn{3}{|l|}{ Metastasis } \\
\hline M0 & 110 & 81 \\
\hline M1 & 9 & 7 \\
\hline $\mathrm{Mx}$ & 16 & 12 \\
\hline \multicolumn{3}{|l|}{ Tumor stage } \\
\hline $\mathrm{T} 1$ & 43 & 32 \\
\hline $\mathrm{T} 2$ & 40 & 22 \\
\hline T3a & 28 & 21 \\
\hline $\mathrm{T} 3 \mathrm{~b}$ & 7 & 5 \\
\hline $\mathrm{T} 4$ & 8 & 6 \\
\hline Unknown & 19 & 14 \\
\hline \multicolumn{3}{|l|}{ Histologic grading } \\
\hline G1 & 5 & 4 \\
\hline $\mathrm{G} 2$ & 34 & 25 \\
\hline G3 & 52 & 38 \\
\hline Unknown & 44 & 53 \\
\hline \multicolumn{3}{|c|}{ Postoperative radiotherapy } \\
\hline No & 111 & 82 \\
\hline Yes & 23 & 17 \\
\hline Unknown & 1 & 1 \\
\hline \multicolumn{3}{|c|}{ Postoperative chemotherapy } \\
\hline No & 112 & 83 \\
\hline Yes & 23 & 17 \\
\hline
\end{tabular}

at $37^{\circ} \mathrm{C}$. All sections were deparaffinized in xylene, rehydrated through a graded alcohol series, and washed in phosphatebuffered saline solution. This buffer was used for all subsequent washes and for dilution of the antibodies. Sections were quenched sequentially in $0.5 \%$ hydrogen peroxide and blocked with diluted $10 \%$ normal horse anti-mouse serum (Vector Laboratories, Burlingame, Calif). A monoclonal antibody raised against p16 (F-12) (Santa Cruz Biotechnology) 


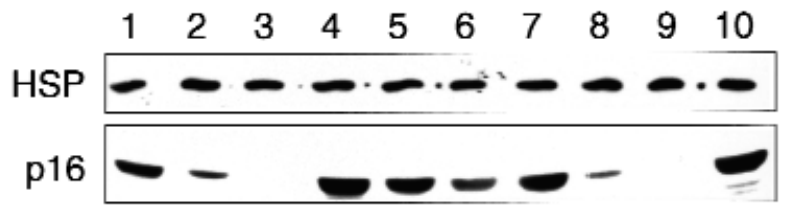

Fig 2. Western blot analysis of a representative panel of lung cancer specimens showing different p16 expression levels. Western blot was normalized with monoclonal antibody anti-heat shock protein (HSP 72/73) purchased from Oncogene Science Diagnostics, Inc (Cambridge, Mass).

was used (dilution 1:100). The incubation time was 60 minutes at room temperature. After being washed in phosphatebuffered saline solution, the slides were incubated with diluted horse anti-mouse biotinylated antibody (Vector Laboratories) for 30 minutes at room temperature.

All slides were processed by the ABC method (Vector Laboratories) for 30 minutes at room temperature. Diaminobenzidine was used as the final chromogen, and hematoxylin was used as the nuclear counterstain. Negative controls for each tissue section were prepared by leaving out the primary antibody. Immunostaining of Saos- 2 cells was used as the positive control ${ }^{15}$ (data not shown).

All samples were processed under the same conditions. Two pathologists (G.G. and F.B.) independently evaluated the staining pattern of the protein. As previously described, ${ }^{15,16} \mathrm{a}$ tumor is considered p16 negative if there is no nuclear staining in any neoplastic cell regardless of cytoplasmatic staining and if admixed non-neoplastic elements do show nuclear immunoreactivity. If the latter are negative as well, the stain is considered uninterpretable. A cutoff of $1 \%$ of positive cells also was adopted. Specimens with less than $1 \%$ of positive cells also were included in the first group (score 0, undetectable expression). All specimens evaluated as positive were scored according to the sequential arbitrary cutoffs: score 1 , from $1 \%$ to $30 \%$ of positive cells (low expression level); score 2 , from $30 \%$ to $60 \%$ of positive cells (medium expression level); and score 3 , more than $60 \%$ of positive cells (high expression level). Analysis of the data with these arbitrary cutoffs was highly statistically significant and, therefore, functionally operative. At least 20 high-power fields were chosen randomly and 2000 cells were counted.

Statistical analysis. We performed a statistical analysis to investigate the relationship between the clinical-pathologic parameters (age, sex, histotype, TNM status, tumor stage, and postoperative radiation or chemotherapy), p16 expression, and the patient survival times. Univariate analysis of survival times was carried out by means of Kaplan-Meier analysis stratified by the individual covariates. In most patients the log rank test was used to test homogeneity of survival over strata. In a few patients, the Wilcoxon test was used because the alternative hypothesis in this last test is that there is a decreasing proportional difference across strata. This test is appropriate when one suspects an effect that may diminish over time. In contrast, the alternative hypothesis in the log rank
Table II. Relationship between p16 expression and tumor stage

\begin{tabular}{lrrccc}
\hline & \multicolumn{5}{c}{ Stage } \\
\cline { 2 - 6 }$p 16$ & 1 & 2 & $3 a$ & $3 b$ & 4 \\
\hline 0 & 2 & 1 & 3 & 1 & 1 \\
1 & 8 & 4 & 12 & 1 & 1 \\
2 & 9 & 8 & 5 & 2 & 1 \\
3 & 13 & 3 & 2 & 2 & 3 \\
\hline
\end{tabular}

test is that there is a proportional difference in survival across strata that remains constant. Multivariate Cox proportional hazards models were fit using all variables that were $<.15$ at the univariate level.

Linear-by-linear and Kruskal-Wallis association tests were used to assess possible associations among clinical-pathologic parameters, Western blot p16 expression levels, and immunohistochemical data. The analysis was performed with the use of Stata 5.0 (Stata Corp 1997, Stata Statistical Software, release 5.0, Stata Corporation, College Station, Tex).

\section{Results}

Table I summarizes the clinical-pathologic features of the patients included in the study. PCR amplification and direct sequencing performed on the 54 freshly frozen specimens did not show any alteration in p16 exons 1 and 2. The immunohistochemical expression of p16 was detected mostly in the nuclei of both normal and neoplastic cells (Fig 1). Thirty-six specimens were considered uninterpretable according to the criteria described in the "Material and methods" section.

The level of agreement between the observers was $91.1 \%$ (123 specimens). In the remaining 12 specimens the score was obtained from the opinion of a third observer (A.G.). In 10 specimens (10.1\%), p16 expression was undetectable. Score 1 was attributed to 27 specimens (27.3\%), score 2 was attributed to 32 specimens (32.3\%), and score 3 was attributed to 30 specimens $(30.3 \%)$. Western blot analysis performed on 54 specimens showed different expression levels of p16 ranging from undetectable levels (6 specimens, $11.1 \%$ ) to high expression levels (15 specimens, 27.7\%) (Fig $2)$. These results correlated highly with the immunohistochemical findings $(P=.0002)$. No correlation was found between p16 immunohistochemical expression and any clinical-pathologic factor (ie, tumor stage and histotype) (Table II). Tables III and IV show the summary of univariate and multivariate analyses of survival times. At the univariate level, the percentage of p16 positive cells, the tumor stage, and the histologic type correlate with patient overall survival. However, in a 
Table III. Univariate Kaplan-Meier analysis

\begin{tabular}{|c|c|c|c|c|}
\hline Factor & $N$ & $\begin{array}{c}\text { Median } \\
\text { survival } \\
(\text { mo })\end{array}$ & $95 \% C I$ & $\mathrm{P}$ value \\
\hline \multicolumn{5}{|l|}{ Sex } \\
\hline 1 & 103 & 27 & $(23,30)$ & \\
\hline 2 & 30 & 32 & $(25,45)$ & .11 \\
\hline \multicolumn{5}{|l|}{ Stage } \\
\hline 1 & 44 & 30 & $(22,46)$ & \\
\hline 2 & 29 & 23 & $(19,30)$ & \\
\hline $3 \mathrm{~A}$ & 26 & 27 & $(11,33)$ & \\
\hline $3 B$ & 7 & 26 & $(9,37)$ & \\
\hline 4 & 8 & 26 & $(19,46)$ & $<.001$ \\
\hline \multicolumn{5}{|l|}{ Radiotherapy* } \\
\hline 0 & 108 & 30 & $(25,33)$ & \\
\hline 1 & 25 & 21 & $(11,29)$ & $.06 \mathrm{LR}$ \\
\hline \multicolumn{5}{|l|}{ p16 status } \\
\hline 0 & 10 & 10 & $(6,14)$ & \\
\hline 1 & 28 & 16 & $(11,19)$ & \\
\hline 2 & 32 & 30 & $(25,33)$ & \\
\hline 3 & 30 & 46 & $(40,54)$ & $<.001$ \\
\hline \multicolumn{5}{|l|}{ Nodal status } \\
\hline 0 & 47 & 28 & $(23,36)$ & \\
\hline 1 & 39 & 27 & $(20,30)$ & \\
\hline 2 & 25 & 21 & $(11,32)$ & \\
\hline 3 & 2 & 21 & $(9,33)$ & .10 \\
\hline \multicolumn{5}{|l|}{ Metastasis } \\
\hline 0 & 107 & 27 & $(23,32)$ & \\
\hline 1 & 10 & 25 & $(19,46)$ & .68 \\
\hline \multicolumn{5}{|l|}{ Tumor size } \\
\hline 1 & 34 & 25 & $(21,40)$ & \\
\hline 2 & 72 & 27 & $(21,30)$ & \\
\hline 3 & 9 & 27 & $(20, X X)$ & \\
\hline 4 & 7 & 26 & $(12,37)$ & .61 \\
\hline \multicolumn{5}{|l|}{ Chemotherapy $^{*}$} \\
\hline 0 & 109 & 28 & $(25,32)$ & \\
\hline 1 & 23 & 25 & $(12,30)$ & .06 \\
\hline \multicolumn{5}{|l|}{ Histotype } \\
\hline Adenocarcinoma & 57 & 30 & $(27,33)$ & \\
\hline Squamous & 54 & 26 & $(19,32)$ & \\
\hline SCLC & 21 & 16 & $(10,40)$ & $.002 \mathrm{WI}^{\dagger}$ \\
\hline
\end{tabular}

$C I$, Confidence interval; $S C L C$, small cell lung cancer.

"Patients who underwent postoperative radiotherapy or chemotherapy were indicated with score $=1$; others were indicated with score $=0$.

${ }^{\dagger} W I P$ values were obtained via the Wilcoxon test. All other $P$ values were based on the log rank (LR) test.

multivariate analysis, models controlled for sex, stage, nodal status, and treatment (radiation and chemotherapy) and stratified by histotype show p16 expression to be an independent prognostic factor with its higher expression correlating with longer patient survival time (Fig 3).

\section{Discussion}

Lung cancer is a disease characterized by a complex array of biomolecular alterations that drive uncon-
Survival by $p 16$

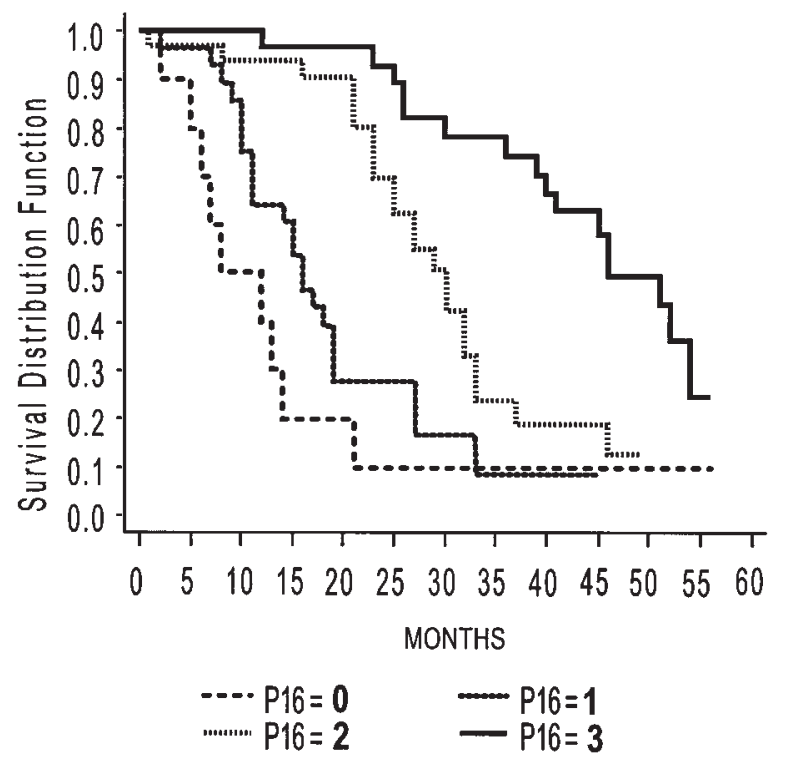

Fig 3. Kaplan-Meier survival percentage curves for patients with lung cancer constructed according to different p16 status.

Table IV. Multivariate Cox proportional hazards

\begin{tabular}{lccrc}
\hline Variable & Risk ratio & Lower & Upper & P value \\
\hline Sex & 0.739 & 0.291 & 1.879 & .53 \\
Stage & & & & \\
$\quad 2$ & 2.452 & 0.415 & 14.485 & .32 \\
$3 \mathrm{a} / 3 \mathrm{~b}$ & 0.756 & 0.184 & 3.105 & .70 \\
$\quad 4$ & 5.276 & 0.717 & 38.799 & .10 \\
$\mathrm{~N}$ & & & & \\
$\quad 1$ & 0.934 & 0.174 & 5.006 & .94 \\
2 & 2.918 & 0.785 & 10.847 & .11 \\
$\mathrm{p} 16$ & & & & \\
1 & 0.234 & 0.077 & 0.715 & .01 \\
2 & 0.049 & 0.014 & 0.168 & $<.001$ \\
3 & 0.025 & 0.007 & 0.093 & $<.001$ \\
\hline
\end{tabular}

trolled growth and metastatic spread. Identification of these alterations could provide a variety of molecular markers, and tests could redefine the criteria for cancer diagnosis and provide for new approaches to treatment. Development of new diagnostic assays then could expand the ability of clinicians to accurately stage tumor development and to better predict clinical outcomes by matching patients to different therapeutic treatments.

These changes that lead to loss of cell cycle inhibition by negative regulators, such as $\mathrm{p} 16$, which releases lung cancer cells from the constraints of cell division, 
are regarded now as target events for new biomolecular assays. We found altered p16 immunohistochemical expression to be a rather frequent event in lung cancer and to be independent of the histologic type of cancer or other clinical-pathologic features. Expression of p16 was undetectable in $10.1 \%$ of the specimens, expressed in less than $30 \%$ of neoplastic cells in $27.3 \%$ of the specimens, expressed in $30 \%$ to $60 \%$ of cells in $32.3 \%$ of the specimens, and detectable in more than $60 \%$ of cells in only $30.3 \%$ of the specimens. Our Western blot analyses highly correlated with these findings $(P=$ .0002). These data are in agreement with the findings of Geradts and Wilson, ${ }^{17}$ who reported a high frequency of aberrant p16 expression in 104 human breast cancers but did not correlate this finding with histopathologic parameters. Washimi and associates, ${ }^{18}$ however, described p16 structural alterations that preferentially affected non-small cell lung cancers in vivo, and Kratzke and coworkers ${ }^{16}$ recently reported a high frequency of p16 aberrant expression in non-small cell lung cancer to be inversely related to the pathologic stage of the disease. In addition, we also conclude that p16 immunohistochemical expression is a favorable independent prognostic factor in lung cancer. Reduction or loss of p16 expression correlates with a worse patient outcome.

These results, obtained on a large number of patients including those with small cell carcinomas, confirm the suggestion of Kratzke and associates ${ }^{16}$ that absent or reduced p16 expression is a negative prognostic indicator.

In this study, PCR amplification and direct sequencing of p16 exons 1 and 2 revealed no mutations, indicating that p16-altered expression in lung cancer is not linked necessarily to mutational events of these gene. Previous studies have reported contrasting results both in lung cancer and in tumors from other anatomic sites. These studies described p16 aberrant expression to be either a frequent consequence of DNA alterations ${ }^{5,18,19}$ or a post-transcriptional event. ${ }^{8,20-23}$ DNA hypermethylation has been proposed recently as an alternative mechanism for p16 gene functional inactivation. ${ }^{24,25}$

In conclusion, our study demonstrated that p16altered expression is a frequent event in lung cancer. These data attribute an important role to this protein during both tumorigenesis and tumor progression in a significant proportion of patients with lung cancer, even though the incidence and the relevance of p16 mutations in this neoplasm remain debatable and its analysis seems inconclusive.

Our results suggest an important role for the immunodetection of this protein on formalin-fixed and paraffin-embedded specimens. If confirmed in larger groups of patients, this simple assay could be of value in the evaluation of the frequently unpredictable behavior of lung cancer.

We thank Dr J. J. Gartland, Thomas Jefferson University medical editor, for editing the manuscript.

\section{REFERENCES}

1. Serrano M, Hanno GJ, Beach D. A new regulatory motif in cellcycle control causing specific inhibition of cyclin D/CDK4. Nature 1993;366:704-7.

2. Tam SW, Shay JW, Pagano M. Differential expression and cell cycle regulation of the cyclin-dependent kinase 4 inhibitor p16 Ink4. Cancer Res 1994;54:5816-20.

3. Li Y, Nichols MA, Shay JW, Xiong Y. Transcriptional repression of the D-type cyclin-dependent kinase inhibitor p16 by the retinoblastoma susceptibility gene product. Cancer Res 1994;54: 6078-82.

4. Parry D, Bates S, Mann DJ, Peters G. Lack of cyclin D-cdk complexes in Rb-negative cells correlates with high levels of p16 INK4/MTS1 tumor suppressor gene product. EMBO J 1995;14: 503-11.

5. Kamb A, Gruis NA, Weaver-Feldhaus J, Lie Q, Harshman K, Tavtigian SV, et al. A cell cycle regulator potentially involved in genesis of many tumor types. Science 1994;264:436-40.

6. Mori T, Miura K, Aoki T, Nishihira T, Mori S, Nakamura Y. Frequent somatic mutation of the MTS1/CDK4I (multiple tumor suppressor/cyclin-dependent kinase 4 inhibitor) gene in esophageal squamous cell carcinoma. Cancer Res 1994;54:3396-7.

7. Otterson GA, Kratzke RA, Coxon A, Kim YW, Kaye FJ. Absence of p16INK4 protein is restricted to the subset of lung cancer lines that retains wild type RB. Oncogene 1994;9:3375-8.

8. Liu Q, Neuhausen S, McClure M, Frye C, Weaver-Felhaus J, Gruis NA, et al. CDKN2 (MTS1) tumor suppressor gene mutations in human tumor cell lines. Oncogene 1995;10:1061-7.

9. Jin J, Harper W, Bigner SH, Bigner DD, Papadopoulos N, Markowitz S, et al. Deletion of p16 and p15 genes in brain tumors. Cancer Res 1994;54:6353-8.

10. Caputi M, Esposito V, Baldi A, De Luca A, Dean C, Signoriello $\mathrm{G}$, et al. p21 waf1/cip1mda-6 expression in non small cell lung cancer: relationship to survival. Am J Respir Cell Mol Biol 1998;18:213-7.

11. Esposito V, Baldi A, De Luca A, Groeger AM, Loda M, Giordano GG, et al. Prognostic role of the cyclin-dependent kinase inhibitor p27 in non-small cell lung cancer. Cancer Res 1997;57: 3381-5.

12. World Health Organization. Histological typing of lung tumors. 2nd ed. Geneva 25-26, 1981. Oncogene 1993;8:1913-9.

13. Beahrs OH, Henson DE, Hutter RVP, Kennedy BJ. Lung: manual for staging of cancer. 4th ed. Chicago. American Joint Committee on Cancer; 1992. p. 115-22.

14. Ohta M, Nagai H, Shimizu M, Rasio D, Berd D, Mastrangelo M, et al. Rarity of somatic and germline mutations of the cyclindependent kinase 4 inhibitor gene, CDK4I, in melanoma. Cancer Res 1994;54:5269-72.

15. Geradts J, Kratzke RA, Niehans GA, Lincoln CE. Immunohistochemical detection of the cyclin-dependent kinase inhibitor 2/Multiple Tumor Suppressor Gene 1 (CDKN2/MTS1) product p16INK4A in archival human solid tumors: correlation with retinoblastoma protein expression. Cancer Res 1995;55:6006-11. 
16. Kratzke RA, Todd MG, Jeffrey BR, Maddaus MA, Niewoehner $\mathrm{DE}$, Niehans GA, et al. Rb and p16ink4a expression in resected non-small cell lung tumors. Cancer Res 1996;56:3415-20.

17. Geradts J, Wilson PA. High frequency of aberrant p16(INK4A) expression in human breast cancer. Am J Pathol 1996;149:15-20.

18. Washimi O, Nagatake M, Osada H, Ueda R, Koshikawa T, Seki $\mathrm{T}$, et al. In vivo occurrence of p16 (MTS1) and p15 (MTS2) alterations preferentially in non-small cell lung cancer. Cancer Res 1995;55:514-7.

19. Jarrard DF, Bova GS, Ewing CM, Pin SS, Nguyen SH, Baylin $\mathrm{SB}$, et al. Deletion, mutational, and methylation analyses of CDKN2 (p16/MTS1) in primary and metastatic prostate cancer. Genes Chromosomes Cancer 1997;19:90-6.

20. DeVos S, Miller CW, Takeuchi S, Gombart AF, Cho SK, Koeffler HP. Alterations of CDKN2 (p16) in non-small cell lung cancer. Genes Chromosomes Cancer 1995;14:164-70.

21. Igaki H, Sasaki H, Tachimori Y, Kato H, Watanabe H, Kimura
$\mathrm{T}$, et al. Mutation frequency of the $\mathrm{p} 16 / \mathrm{CDKN} 2$ gene in primary cancers in the upper digestive tract. Cancer Res 1995;55: 4321-3.

22. Sun Y, Hildesheim A, Lanier AE, Cao Y, Yao KT, Raab-Traub N, et al. No point mutation but decreased expression of the p16/MTS1 tumor suppressor gene in nasopharyngeal carcinomas. Oncogene 1995;10:785-8.

23. Berns EM, Klijn JG, Smid M, Van Staveren IL, Gruis NA, Foekens JA. Infrequent CDKN2 (MTS1/p16) gene alterations in human primary breast cancer. Br J Cancer 1995;72:964-7.

24. Bartsch D, Shevlin DW, Tung WS, Kisker O, Wells SA Jr, Goodfellow PJ. Frequent mutations of CDKN2 in primary pancreatic adenocarcinomas. Genes Chromosomes Cancer 1995;14: 189-95.

25. Otterson GA, Khleif SN, Chen W, Coxon AB, Kaye FJ. CDKN2 gene silencing in lung cancer by DNA hypermethylation and kinetics of p16 protein induction by 5-aza 2'deoxycytidine. Oncogene 1995;11:1211-6.

\section{Online-www.aats.org}

Now you can get The Journal of Thoracic and Cardiovascular Surgery online. The Journal online brings you faster delivery time, easy searching of current and back issues, links to PubMed, AATS, WTSA and other important sites, and more. Visit the Journal online today. 